\title{
Research on the Transformation Path of BP under the Dual- carbon Background
}

\author{
Xueying Wang \\ China University of Petroleum (Beijing), Changping District, Beijing, 102249, China
}

\begin{abstract}
Nowadays, the oil and gas industry is facing a huge financial challenge, because it has been hit by the double blow of the COVID-19 pandemic and low oil prices. This, coupled with the global consensus on low-carbon energy, forces BP to seek a balance between oil business and lowcarbon, sustainable development, and began to look for new value growth points to accelerate the pace of low-carbon transformation.
\end{abstract}

Keywords: British Petroleum (BP); Low Carbon; Energy; Transition.

\section{Introduction}

BP is an integrated energy company, covering upstream business, downstream business and renewable energy. At present, BP operates in 79 countries and regions around the world, with proven oil and gas reserves of 19.341 billion barrels of oil equivalent and annual crude oil trading volume of 4 billion barrels, accounting for $20 \%$ of the global crude oil trading volume.

\section{BP's Zero-carbon Goal}

In February 2020 BP set out their ambition to be a net zero company by 2050 or sooner and to help the world get to net zero. This ambition is supported by 10 aims. Taken collectively, these set out a path that BP believe is consistent with the Paris goals.

\subsection{Objective Statement}

Aim 1: net zero operations

BP's aim 1 is to be net zero across their entire operations on an absolute basis by 2050 or sooner. This aim relates to Scope 1 and 2 GHG emissions (around 55Mte CO2e in 2019).

Aim 2: net zero oil and gas

Aim 2 is to be net zero on an absolute basis across the carbon in their upstream oil and gas production by 2050 or sooner.

Aim 3: halving intensity

BP's aim 3 is to cut the carbon intensity of the products they sell by $50 \%$ by 2050 or sooner. This is a life cycle carbon intensity approach, per unit of energy. It covers marketing sales of energy products and potentially, in future, certain other products.

Aim 4: reducing methane

Their aim 4 is to install methane measurement at all BP's existing major oil and gas processing sites by 2023, publish the data, and then drive a 50\% reduction in methane intensity of their operations. And BP will work to influence their joint ventures to set their own methane intensity targets of $0.2 \%$.

Aim 5: more investment for new energies

Aim 5 is to increase the proportion of investment BP make into their non-oil and gas businesses. Over time, as investment goes up in low and zero carbon, we see it going down in oil and gas.

Aim 6: Advocating

Aim 6 is to more actively advocate for policies that support net zero, including carbon pricing. BP have stopped corporate reputation advertising campaigns and this is enabling BP to redirect resources to promote well designed climate policies.

Aim 7: Incentivizing employees 
Aim 7 is to incentivize BP's global workforce to deliver on their aims and mobilize them to become advocates for net zero. This will include continuing to allocate a percentage of remuneration linked to emissions reductions for leadership and employees.

Aim 8: Aligning associations

Aim 8 is to set new expectations for BP's relationships with trade associations around the globe. $\mathrm{BP}$ will make the case for their views on climate change within the associations BP belong to and they will be transparent where they differ.

Aim 9: Transparency leader

Aim 9 is to be recognized as an industry leader for the transparency of BP's reporting. On 12 February 2020, BP declared their support for the recommendations of the Task Force on Climaterelated Financial Disclosures (TCFD).

Aim 10: Clean cities and corporates

Aim 10 is to launch a new team to create integrated clean energy and mobility solutions. BP launched their regions, cities and solutions team in 2020. It will help countries, cities and corporations around the world decarbonize.

\subsection{Strategic Path to Achieve the Goal}

\section{Low carbon electricity and energy}

Through BP's gas \& low carbon energy business, they aim to grow scale. BP's low carbon businesses are complemented by integrated gas, which has an important role in the energy transition.

(1) Growing BP's renewables portfolio, including offshore wind and solar.

(2) Building an integrated low carbon electricity position in select developed and emerging markets.

(3) Growing BP's integrated gas position, building on BP's high-value equity upstream gas, BP's LNG portfolio« and BP's marketing capability.

(4) Scaling BP's bioenergy business, focusing on biofuels, biogas and biopower.

(5) Accelerating to take early positions in hydrogen and carbon capture, use and storage.

2. Convenience and mobility

BP's customers \& products business group is an integral part of BP's growth and returns strategy. BP aim to put customers at the heart of everything they do.

(1) Expanding and scaling BP's differentiated fuels and lubricants offers in growth markets, aiming to help shape these markets over time to lean into the transition to low carbon mobility.

(2) Redefining convenience through partnerships with some of the world's leading brands and continuing to develop innovative offers, making buying BP's retail goods and fuels even more convenient for customers.

(3) Developing next-gen mobility solutions, including electrification, sustainable fuels and hydrogen.

3. Resilient and focused hydrocarbons

BP aim to produce the affordable hydrocarbon energy and products the world needs, and generate cash to fund BP's operations and BP's transformation to an Integrated Energy Company.

(1) Always putting safety first. Aiming to eliminate life-changing injuries and the most serious process safety events.

(2) Reducing emissions, aligned with BP's aims, while delivering the energy the world needs. Transforming operations and improving efficiency.

(3) Maintaining a resilient portfolio through investment efficiency and high grading. Flexibly deploying talent to BP's most valuable opportunities and to solve BP's biggest issues. 


\section{Natural Gas Business}

\subsection{New Natural Gas Production Project}

Of the 31 new upstream projects put into production by BP in 2016-2021, 18 are natural gas projects, as shown in figure 1 . Of the nine oil and gas production projects in 2019 , four are natural gas projects.

Table 1. BP's newly commissioned natural gas projects in 2015-2021

\begin{tabular}{|c|c|c|c|}
\hline Project Name & $\begin{array}{l}\text { Production } \\
\text { Time }\end{array}$ & Project Description & Area \\
\hline Matapal & $\begin{array}{c}\text { September } \\
2021\end{array}$ & $\begin{array}{l}\text { BP Trinidad and Tobago LLC (bpTT) confirms its } \\
\text { Matapal project has safely achieved first gas. The major } \\
\text { milestone was achieved ahead of schedule and under } \\
\text { budget despite the constraints brought about by the } \\
\text { COVID-19 pandemic. }\end{array}$ & Trinidad \\
\hline $\begin{array}{l}\text { Trans Adriatic } \\
\text { Pipeline }\end{array}$ & $\begin{array}{c}\text { November } \\
2020\end{array}$ & $\begin{array}{l}\text { The Trans Adriatic Pipeline is a strategic piece of } \\
\text { energy infrastructure that forms the last link in the mega } \\
\text { Southern Gas Corridor (SGC) project. SGC covers several } \\
\text { separate energy projects that stretch over 3,500 kilometres, } \\
\text { crossing seven countries and involving more than a dozen } \\
\text { major companies. }\end{array}$ & $\begin{array}{l}\text { Seven } \\
\text { countries } \\
\text { including } \\
\text { Greece, } \\
\text { Albania and } \\
\text { Italy } \\
\end{array}$ \\
\hline $\begin{array}{l}\text { West Nile Delta - } \\
\text { Giza / Fayoum }\end{array}$ & $\begin{array}{l}\text { February } \\
2019\end{array}$ & $\begin{array}{l}\text { The project produces natural gas from the Giza and } \\
\text { Fayoum gas fields and is developed for long-distance } \\
\text { recharge as deep water for existing onshore plants. }\end{array}$ & Egypt \\
\hline Angelin, Trinidad & $\begin{array}{l}\text { February } \\
2019\end{array}$ & $\begin{array}{l}\text { The Angelin project developed four wells and built a new } \\
\text { platform at a depth of about } 215 \text { feet } 40 \text { miles off the } \\
\text { southeast coast of Trinidad. Natural gas from Anjilin flows } \\
\text { through a new 13-mile pipeline to the Serrette platform } \\
\text { hub. }\end{array}$ & Trinidad \\
\hline $\begin{array}{l}\text { Culzean, North } \\
\text { Sea, UK }\end{array}$ & June 2019 & $\begin{array}{l}\text { Culzean is a 1.2Tcf high pressure and high temperature } \\
\text { (HPHT) lean gas condensate field, located about } 140 \text { miles } \\
\text { east of Aberdeen in block } 22 \text { / 25a in the central North Sea } \\
\text { with a water depth of } 300 \mathrm{ft} \text {. }\end{array}$ & $\begin{array}{l}\text { United } \\
\text { Kingdom- } \\
\text { North Sea }\end{array}$ \\
\hline India KGD6 - MJ & June 2019 & $\begin{array}{l}\text { In the third phase of natural gas development in KG D6, } \\
\text { seven undersea wells will be connected to a new floating } \\
\text { production and storage tanker to process and separate } \\
\text { liquids. }\end{array}$ & India \\
\hline $\begin{array}{c}\text { Atoll Phase 1, } \\
\text { Egypt }\end{array}$ & $\begin{array}{l}\text { February } \\
2018\end{array}$ & $\begin{array}{l}\text { The atoll phase I project is an early production plan that } \\
\text { involves the upgrading of existing exploration and } \\
\text { production wells, the drilling of two other wells, the } \\
\text { installation of the necessary submarine infrastructure and } \\
\text { the upgrading of existing onshore facilities required for } \\
\text { on-site production. }\end{array}$ & Egypt \\
\hline $\begin{array}{c}\text { Shah Deniz Stage } \\
\text { 2, Azerbaijan }\end{array}$ & June 2018 & $\begin{array}{l}\text { The } \$ 28 \text { billion project run by BP is the first undersea } \\
\text { development in the Caspian Sea. The project includes } 26 \\
\text { undersea oil wells, an undersea production system, two } \\
\text { offshore platforms connected to bridges and } 500 \mathrm{~km} \text { of } \\
\text { subsea oil pipelines. }\end{array}$ & Azerbaijan \\
\hline Western Flank B & $\begin{array}{l}\text { October } \\
2018\end{array}$ & $\begin{array}{c}\text { The Western Flank B project will develop the Keast, } \\
\text { Dockrell, Sculptor-Rankin, Lady Nora and Pemberton } \\
\text { fields through eight subsea wells connected to the } \\
\text { Goodwyn A platform. }\end{array}$ & Australia \\
\hline $\begin{array}{l}\text { West Nile Delta- } \\
\text { Taurus / Libra, } \\
\text { Egypt }\end{array}$ & $\begin{array}{c}\text { March } \\
2017\end{array}$ & $\begin{array}{l}\text { The WND development includes five gas fields spanning } \\
\text { two offshore concession blocks operated by BP (Northern } \\
\text { Alexandria and Western Mediterranean Deepwater). }\end{array}$ & Egypt \\
\hline
\end{tabular}




\begin{tabular}{|c|c|c|c|}
\hline $\begin{array}{l}\text { Trinidad Onshore } \\
\text { Compression, } \\
\text { Trinidad and } \\
\text { Tobago }\end{array}$ & April 2017 & $\begin{array}{l}\text { The Trinidad onshore compression project will use } \\
\text { additional imported compressors from the Point Fortin } \\
\text { Atlantic LNG plant to increase production of BP Trinidad } \\
\text { and Tobago LLC (bpTT) low pressure wells in the existing } \\
\text { area of the Columbus Basin. }\end{array}$ & Trinidad \\
\hline $\begin{array}{l}\text { Persephone, } \\
\text { Australia }\end{array}$ & July 2017 & $\begin{array}{c}\text { The Persephone gas field is located } 135 \mathrm{~km} \text { northwest of } \\
\text { Karasa City, Western Australia, with a water depth of } \\
\text { about } 126 \mathrm{~m} \text {. It costs } \$ 1.50 \text {. }\end{array}$ & Australia \\
\hline $\begin{array}{l}\text { Juniper, Trinidad } \\
\text { and Tobago }\end{array}$ & $\begin{array}{c}\text { August } \\
2017\end{array}$ & $\begin{array}{l}\text { The Juniper network facility will use the Corallita and } \\
\text { Lantana fields } 50 \text { miles off the southeast coast of Trinidad } \\
\text { to produce natural gas at a depth of about } 360 \mathrm{ft} \text {. }\end{array}$ & Trinidad \\
\hline $\begin{array}{l}\text { Khazzan Phase 1, } \\
\text { Oman }\end{array}$ & $\begin{array}{l}\text { September } \\
2017\end{array}$ & $\begin{array}{l}\text { Mining the gas tightly hidden in Kazan's ancient hard rock } \\
\text { is challenging. }\end{array}$ & Oman \\
\hline Zohr, Egypt & $\begin{array}{l}\text { December } \\
2017\end{array}$ & $\begin{array}{l}\text { The field, a joint venture between Eni and Egyptian } \\
\text { General Petroleum Corporation (EGPC), is the largest } \\
\text { natural gas discovery to date in the Mediterranean. }\end{array}$ & Egypt \\
\hline $\begin{array}{l}\text { Point Thomson, } \\
\text { Alaska }\end{array}$ & April 2016 & $\begin{array}{l}\text { The project will remove condensed water from the } \\
\text { produced gas for export and then re-inject natural gas into } \\
\text { the reservoir. }\end{array}$ & Alaska \\
\hline $\begin{array}{l}\text { In Amenas } \\
\text { Compression, } \\
\text { Algeria }\end{array}$ & $\begin{array}{l}\text { December } \\
2016\end{array}$ & $\begin{array}{l}\text { The In Amenas joint venture, one of the largest wet gas } \\
\text { projects in Algeria, involves the development and } \\
\text { production of natural gas and gas-liquid from oilfields in } \\
\text { the Illizi basin in southeastern Algeria. }\end{array}$ & Algeria \\
\hline $\begin{array}{l}\text { Angola LNG } \\
\text { (restart) }\end{array}$ & June 2016 & $\begin{array}{l}\text { Angola resumes production of liquefied natural gas } \\
(\mathrm{LNG}) \text {, which is expected to be loaded and exported in the } \\
\text { near future. }\end{array}$ & Angola \\
\hline
\end{tabular}

\subsection{Natural Gas M\&A Project}

1. On December 5, 2017, BP acquired a 3.06\% stake in the Tangji liquefied Natural Gas (LNG) project.

2. In February 2018, BP announced a $\$ 7.2$ billion offer for a $30 \%$ stake in 23 oil and gas contracts operated by Reliance Industries of India.

3. In July 2018, BP acquired BHP Billiton's onshore assets in the United States.

4. In August 2018, BP began to lay out the Oceania natural gas market and signed a natural gas procurement agreement with Papua New Guinea.

5. In October 2020, BP started production from the Ghazeer field in the Omani desert ahead of schedule.

6. In April 2021, BP announces gas production from third stage of West Nile Delta development in Egypt.

\section{New Energy Business}

\subsection{New Energy Business Development Scale}

(1) Wind Power

BP's wind assets in the United States include 11 onshore wind farms, ranging from Maui in Hawaii to the hills of northeastern Pennsylvania. Net generating capacity exceeds $1000 \mathrm{MW}$, which is enough to power all houses in Dallas.

(2) Biofuels

Biofuel technology is the key to achieving a "farm of the future" for BP's biofuel business in Brazil. BP's 50\% stake in BP Bunge Bioenergia, a Brazilian joint venture with Bunge Limited, a leading agricultural commodities company, has boosted its existing biofuel business by more than $50 \%$. 
(3) Solar Energy

LightsBP'sce BP, a subsidiary of BP, has acquired three solar projects in Aragon, Spain, with a total capacity of 703MW. The company said the portfolio was acquired from Grupo Jorge and that three projects would be built in 2022 .

(4) Energy Storage Battery

In 2018, BP announced that it had reached an agreement to acquire Chargemaster, the largest electric vehicle (EV) charging company in the UK. Chargemaster is the largest electric vehicle charging network operator in the UK and a leading supplier of electric vehicle charging facilities.

\subsection{Acquisitions and Mergers of New Energy Businesses}

The following table lists the new energy projects that BP has acquired and acquired after 2015.

Table 2. New energy projects acquired by BP

\begin{tabular}{|c|c|c|}
\hline year & Type & Project profile \\
\hline $\begin{array}{l}\text { December } \\
2017\end{array}$ & $\begin{array}{l}\text { Solar } \\
\text { Energy }\end{array}$ & $\begin{array}{c}\text { Buy a 43\% stake in British solar company Light sBP'sce for \$200 million, and } \\
\text { return to the solar industry. }\end{array}$ \\
\hline June 2018 & Electricity & BP to acquire the UK's largest electric vehicle charging company--Chargemaster \\
\hline July 2019 & $\begin{array}{l}\text { Solar } \\
\text { Energy }\end{array}$ & $\begin{array}{l}\text { LightsBP'sce BP acquires about two GW greenfield solar projects from Enerlife, } \\
\text { which are at various stages of development in Brazil. }\end{array}$ \\
\hline $\begin{array}{l}\text { October } \\
2019\end{array}$ & $\begin{array}{l}\text { Solar } \\
\text { Energy }\end{array}$ & $\begin{array}{l}\text { Enter the Spanish solar market by acquiring a portfolio of 300MW projects in } \\
\text { Zaragoza, Spain. }\end{array}$ \\
\hline $\begin{array}{l}\text { December } \\
2019\end{array}$ & $\begin{array}{l}\text { Solar } \\
\text { Energy }\end{array}$ & $\begin{array}{c}\text { BP will acquire an additional stake in LightsBP'sce BP, increasing its interest in } \\
\text { the company from } 43 \% \text { to } 50 \% \text {. This creates a new } 50 / 50 \text { joint venture between } \\
\text { the management of LightsBP'sce BP and BP. }\end{array}$ \\
\hline $\begin{array}{c}\text { Novemb } \\
\mathbf{2 0 2 0}\end{array}$ & Hydrogen & $\begin{array}{r}\text { BP and Ørsted signed a Letter of Intent } \\
\text { project for industrial-scale pro }\end{array}$ \\
\hline $\begin{array}{l}\text { September } \\
2020\end{array}$ & $\begin{array}{l}\text { Offshore } \\
\text { wind }\end{array}$ & $\begin{array}{r}\text { BP has annou } \\
\text { major offshore wi } \\
\text { furt }\end{array}$ \\
\hline July 2021 & $\begin{array}{l}\text { Offshore } \\
\text { wind }\end{array}$ & $\begin{array}{l}\text { BP has formed an exclu } \\
\text { UK-based renewable }\end{array}$ \\
\hline May 2021 & $\begin{array}{l}\text { Solar } \\
\text { energy }\end{array}$ & $\begin{array}{l}\text { Lightsource BP announces } € 900 \text { million solar investment in Portugal. The } \\
\text { projects are in the early development stage and will be located in the regions of } \\
\text { Moura, Castelo Branco, Mogadouro, Chamusca and Viseu. }\end{array}$ \\
\hline March 20 & Hydrogen & $\begin{array}{l}\text { Proposed project in Teesside would be the largest in the UK, producing up to } \\
1 \mathrm{GW} \text { of 'blue' hydrogen }-20 \% \text { of the UK's hydrogen target - by } 2030 \text { and } \\
\text { supporting development of region as UK's first hydrogen transport hub. }\end{array}$ \\
\hline
\end{tabular}

\section{References}

[1] BP Group Annual Report (2020-2015).

[2] BP Group Sustainability Report (2020-2015).

[3] BP Group Investor Handbook (2020-2015). 